\title{
Ethanol Production from Lignocellulosic Materials by Fermentation Process Using
} Yeast

\section{*BAKARE, V; ABDULSALAMI, MS; ONUSIRIUKA, BC; APPAH, J; BENJAMIN, B; NDIBE, TO}

\author{
Department of Biological Sciences, Nigerian Defence Academy, P.M.B. 2109, Kaduna- Nigeria \\ *Corresponding Author Email: bakarevictoria2@gmail.com
}

\begin{abstract}
Rapid industrialization and growing population result to high demand for energy. Depletion and rise in price of petroleum as well as environmental pollution necessitates the need for alternative source of fuel, hence bioethanol production. Rice bran (Oryza sativa), Corn bran (Zea mays) and Sorghum bran (Sorghum guinense) and saw dusts of Khaya senegalensis (Red wood), Terminalia superba (Black wood), Gmelina arborea (White wood), were used for the study. The yeasts used for the study were isolated from fermented beverages (Sorghum beer, Millet beverage and Palm wine). The results of the lignocellulosic biomass of white saw dust, red saw dust, black saw dust, rice bran, corn bran and sorghum bran revealed cellulose components as $77.78 \%, 75.55 \%, 68.59 \%, 64.83 \%, 54.82 \%$ and $55.14 \%$ respectively. A total of 25 yeasts were isolates and identified using API 20C AUX strip. The yeast isolates, K2, B5, B7 and P1 had the highest ethanol tolerance value of $14 \%$. The results showed that the ethanol-producing ability of the yeast isolates ranged from $4.1 \%$ to $10.3 \%$. Fourier Transform Infrared Spectrophotometer (FTIR) and Gas Chromatography and Mass Spectrometry (GC-MS) analyses showed that ethanol is the main compound produced by yeasts from the lignocellulosic materials. This study revealed that Saccharomyces cerevisiae isolated from palm wine (P1) is best in ethanol production and tolerance, and this high prolific strain can be exploited or engineered for ethanol production. Therefore, Lignocellulosic biomasses are recommended as raw materials for producing ethanol, which is a promising alternative energy source as against the depleting petroleum.
\end{abstract}

DOI: https://dx.doi.org/10.4314/jasem.v23i5.17

Copyright: Copyright $\odot 2019$ Bakare et al. This is an open access article distributed under the Creative Commons Attribution License (CCL), which permits unrestricted use, distribution, and reproduction in any medium, provided the original work is properly cited.

Dates: Received: 29 April 2019; Revised: 25 May 2019; Accepted 29 May 2019

Keywords: Ethanol, Lignocellulose, Yeasts, Beverages and Saccharomyces cerevisiae.

The demand for energy is increasing due to growing population and industrialization, implying that energy shortage will be a global problem in the nearest future. Bioethanol has emerged as a favourable alternative for petroleum-based liquid fuels. The world production of bioethanol increased from 50 million cubic metres in 2007 to over 100 million cubic metres in 2012 (Kang et al., 2014). The use of ethanol in automobiles as an alternative fuel presents a viable option for improving energy security and reducing greenhouse emissions (Wyman, 1990). This has attracted worldwide attention to its production on a large scale while enhancing the economic status of a country (Cardona and Sanchez, 2007). Nearly $73 \%$ of bioethanol are produced globally (Balat et al., 2008). Ethanol produced from lignocellulosic materials is called second generation bioethanol and regarded as a carbon neutral fuel. Wood is one of the most important and adequate source of the lignocellulosic materials used for ethanol production (Okuda et al., 2007). Lignocelluloses in nature are derived from wood, grass, agricultural residues, forestry wastes and municipal solid wastes. They consist of three major components of polymers: cellulose, hemicelluloses and lignin. In addition, small amounts of other materials such as ash, proteins, pectin can be found in lignocellulosic residues in different degrees based on the sources (Saha, 2003). The plant biomass of the lignocellulose comprises on an average $23 \%$ lignin, $40 \%$ cellulose, and $37 \%$ hemicelluloses by dry weight (Sa-Pereira et al., 2003). This biomass has been recognized as a major renewable energy source to supplement declining fossil fuel sources of energy, and it is expected to play a crucial role in the world's future energy supplements (Amiri et al., 2014). More so, due to the rise in petroleum prices and environmental problems resulting from greenhouse gas emissions, the demands for traditional fossil fuels in recent years have increased drastically and there has been increasing interest towards an alternative sustainable energy resource such as bioethanol (Zhang et al., 2010). The transportation sector is unfortunately heavily dependent on crude oil as the only source of raw materials and the world is faced with a progressive 
depletion of crude oil and traditional fossils fuel. Being an oxygenated fuel when blended with gasoline, ethanol can be widely used for transportation purpose across the globe (Prasad et al., 2007). A way of addressing this problem could be through the usage of lignocellulosic materials to produce ethanol which will significantly lower the emission of exhaust gases that will result in clean and eco-friendly environment. More importantly, lignocellulosic materials do not compete with food crops and are less expensive than conventional agricultural feed stocks (Prasad et al., 2007). Ethanol as an alternative fuel can be obtained from forestry, agricultural, industrial and urban residues.

Therefore, the objective of the study was to produce ethanol from lignocellulosic materials by fermentation process using yeast.

\section{MATERIALS AND METHODS}

Sample Collection and Processing: Lignocellulosic materials used in this study include: Rice bran (Oryza sativa), Corn bran (Zea mays), Sorghum bran (Sorghum guinense) and Saw dusts of Oswalee (red wood) (Khaya senegalensis), Afara (black wood) (Terminalia superba), Obeche (white wood) (Gmelina arborea). The samples were air-dried at room temperature for two weeks to remove moisture and were pulverized in order to reduce the particles. The pretreated samples were packaged in clean sealed plastic containers, labeled appropriately and stored at room temperature for further use.

The Proximate Composition of the Lignocellulosic Materials: Each of the pulverized samples that has been processed and sieved was analyzed proximately using the AOAC (1990) method, for dry matter, ash content, crude fiber and crude protein.

Determination of Dry Matter Content: Six clean crucibles were dried to a constant weight in an oven at $105^{\circ} \mathrm{C}$, cooled in a desiccator and weighed $\left(\mathrm{W}_{1}\right)$. Two grams $(2 \mathrm{~g})$ of each sample was weighed into the crucibles $\left(\mathrm{W}_{2}\right)$ and dried in the oven. The crucible and its contents were cooled to room temperature in a desiccator and reweighed. The procedure continued until a constant weight was obtained $\left(\mathrm{W}_{3}\right)$. The percentage moisture content was calculated thus:

$\%$ moisture content $=\frac{\mathrm{W}_{2}-\mathrm{W}_{3}}{\mathrm{~W}_{2}-\mathrm{W}_{1}} \times 100$

Determination of Ash Content: Two grams of the pulverized sample was weighed $\left(\mathrm{W}_{2}\right)$ into a previously weighed, clean crucible $\left(\mathrm{W}_{1}\right)$. The sample was then ignited and cooled in a desiccator before being taken to the furnace. After maintaining the sample at $550^{\circ} \mathrm{C}$ in a muffle furnace for eight hours, the crucible and its residual ash were removed from the furnace and then allowed to cool to room temperature in a desiccator and weight $\left(\mathrm{W}_{3}\right)$. The ash content was calculated thus:

$\% \operatorname{ash}=\frac{\mathrm{W}_{2}-\mathrm{W}_{3}}{\mathrm{~W}_{2}-\mathrm{W}_{1}} \times 100$

Determination of Crude Fibre Content: Two grams of the sample was weighed into a $500 \mathrm{ml}$ round bottom flask, then $100 \mathrm{ml}$ of $0.023 \mathrm{M}$ sulphuric acid solution was added and the mixture boiled under reflux for 30 minutes. The hot solution was quickly filtered under suction. The residues were transferred into the flask and $100 \mathrm{ml}$ of $0.312 \mathrm{M}$ sodium hydroxide solution was added and the mixture boiled again under reflux for 30 minutes and filtered under suction. The insoluble residue was washed until it was base free and dried to a constant weight in an oven set at $100^{\circ} \mathrm{C}$, cooled in a desiccator and weighed $\mathrm{C}_{2}$. The residues were incinerated in a muffle furnace at $550^{\circ} \mathrm{C}$ for 2 hours, cooled on a desiccator and reweighed $\mathrm{C}_{3}$. The crude fiber content was calculated as:

$\%$ crude fiber $=\frac{\mathrm{C}_{2}-\mathrm{C}_{3}}{\mathrm{~W}} \times 100$

Determination of Crude Protein: Two grams of the sample were weighed into a $100 \mathrm{ml}$ Kjeldahl digestion flask and twenty five millilitres $(25 \mathrm{ml})$ of concentrated sulphuric acid were added into the flask. Thereafter, the content in the Kjeldahl digestion flask was heated slowly at first in a Kjeldahl digestion heating unit until fretting subsided and then more vigorously until the green digest was obtained. Then $100 \mathrm{ml}$ of $40 \%$ sodium hydroxide solution was added. The solution was steam-distilled and the liberated ammonia was trapped in a $250 \mathrm{ml}$ conical flask containing $10 \mathrm{ml}$ of $4 \%$ Boric acid and a drop of mixed indicator (methyl red and methyl blue in a ratio of $2: 1$ ). The content of the conical flask was titrated with $0.1 \mathrm{M}$ hydrochloric acid $(\mathrm{HCl})$ and end point was indicated by a change from greenish to pink colour. The volume of the acid used for each distillate as well as the blank was noted.

Determination of Fractional Composition of Cellulose, Hemicellulose and Lignin: The different components present in lignocellulosic materials used in this study were determined by sequential chemical extraction of the substrates using Harper and Lyach (1981) method. One gram (1g) each of the dried samples (dried at $60^{\circ} \mathrm{C}$ for 16 hours) was weighed into $150 \mathrm{ml}$ conical flasks, and then hot-water and hotethanol soluble fractions were determined.

BAKARE, V; ABDULSALAMI, MS; ONUSIRIUKA, BC; APPAH, J; BENJAMIN, B; NDIBE, TO 
Determination of Total Carbohydrate Content of the Lignocellulosic Materials: The determination of total carbohydrates by Phenol-Sulphuric Acid Method was adopted as described by Salehi et al. (2013). A homogeneous suspension of the pulverized samples were made by weighing $0.005 \mathrm{~g}$ each of the sample into $10 \mathrm{ml}$ of $1 \mathrm{~N} \mathrm{NaOH}$ solution and were heated to about $90^{\circ} \mathrm{C}$ in order to make fine suspension. Total carbohydrates in unknown samples were then determined from the prepared suspensions.

Isolation of Yeast from Fermented Beverages: For screening of yeasts, three different types of fermented beverages (Sorghum beer, Millet beverage and Palm wine) were randomly purchased from well-known market and at the rural seller shops in Kaduna, Kaduna State. Yeast Isolates were obtained using dilution plate count techniques. Adopting the method of Martini et al. (1996), serial dilution of the samples was prepared using sterile distilled water as diluents. The pure colonies were transferred onto Yeast Extract Peptone Glucose (YEPG) agar slants for subsequent identification and stored at refrigeration temperature of about $4^{\circ} \mathrm{C}$ to $10^{\circ} \mathrm{C}$.

Yeasts Identification Test with API 20C AUX: The isolates obtained were identified using API 20C AUX a standardized system (BioMerieux, France), containing identification numeric profile catalogue for yeasts. Yeast isolates grown between 18 to 24 hours was aseptically picked and emulsified in $2 \mathrm{ml}$ sterile saline solution, whose turbidity was adjusted to equivalent of 2 McFarland. Hundred microlitres (100ul) of this suspension was transferred to each cupule (well) of the identification strip. The dehydrated composition of the API 20C AUX strip is given in the list of tests: D-glucose (GLU), glycerol (GLY), calcium 2-keto-gluconase (2KG), LArabinose (ARA), D - Xylose (XYL), Adonitol (ADO), Xylitol (XLT), D - Galactose (GAL), Inositol (INO), D-Sorbitol (SOR), Methyl- $\alpha$-DGlucopyranoside (MDG), N-acetylglucosamine (NAG), D-cellobiose (CEL), D-Lactose (LAC), DMaltose (MAL), D-saccharose (SAC), D-Trehalose (TRE), D-Melezitose (MLZ), and D-Raffinose (RAF).

Ethanol Tolerance: The yeast isolates were screened for its efficiency in ethanol; the tolerance of each isolate was studied by allowing the yeast to grow in liquid YEPG medium as described by Osho et al. (2010). The prepared medium was dispensed into $(150 \mathrm{ml})$ Erlenmeyer flasks, and sterilized by autoclaving at $121^{\circ} \mathrm{C}$ for 15 minutes. The medium in the flasks were allowed to cool to a temperature of about $45^{\circ} \mathrm{C}$ and absolute ethanol was added in varying percentage concentrations of $6 \%, 8 \%, 10 \%, 12 \%$, $14 \%, 16 \%$.

Acid Hydrolysis of Lignocellulosic Substrates: Adopting the method of Dawson (2007), the experimental procedure for each of the substrate was carried out in triplicates. Five grams of each samples was separately mixed with $100 \mathrm{ml}$ of $1 \mathrm{M} \mathrm{H}_{2} \mathrm{SO}_{4}$ in $250 \mathrm{ml}$ Erlenmeyer flasks and were left to soak for 24 hours. The samples were then autoclaved at $121^{\circ} \mathrm{C}$ for 15 minutes.

Determination of Ethanol-Producing Ability of Yeast Isolates: Quantitative estimation of ethanol produced from the samples was determined by the method of Salehi et al. (2013). The yeast strains were tested for their ethanol production efficiency in $250 \mathrm{ml}$ Erlenmeyer flasks which contained the hydrolyzed substrate and 50ml of YEPG broth. A loopful of each of the 24 hours yeast isolate was aseptically inoculated separately into the flasks and was incubated at room temperature of about $28^{\circ} \mathrm{C} \pm 2$ for $72 \mathrm{hrs}$. The fermented culture media were aseptically poured into centrifuge tubes and were centrifuged at $10000 \mathrm{rpm}$ for 10 minutes in a centrifuge machine so as to remove the yeast cells and other solids present. The ethanol content was determined in the supernatant. Optical density (O.D) was measured at $620 \mathrm{~nm}$ on UV-Visible spectrophotometer. The blank was prepared in the same manner without ethanol. Ethanol production was assayed by comparing with standard ethanol curve.

Distillation and Quantification of the Distilled Ethanol: The fermented samples were collected and were distilled using a laboratory fractional distillation unit. The sample was separately poured into the distillation flask and heated until boiling point temperature of ethanol $\left(78.5^{\circ} \mathrm{C}\right)$ was reached on the thermometer attached to the setup. The distillate (ethanol) was collected in the receiving chamber by condensation process, then the volume of distillate collected for each sample was measured and stored in a screw cap container and they were labeled appropriately. The quantity of ethanol produced in $\mathrm{g} / \mathrm{L}$ was calculated by multiplying the volume of the distillate collected at $78^{\circ} \mathrm{C}$ by the density $(0.8033 \mathrm{~g} / \mathrm{ml})$ of ethanol and ethanol content recovered after distillation was assayed (Nzelibe and Okafoagu, 2007).

Ethanol Analysis by Fourier Transform Infrared Spectrometer (FTIR): FTIR was carried out for detection of changes in functional groups that occurred in distillate (ethanol) produced from lignocellulosic substrates. The FTIR spectra were analyzed and recorded based on their absorption band mode of 
infrared wave lengths to detect the functional groups of the distillates using (Shimadzu FTIR-8400S) of the National Research Institute for Chemical Technology, Zaria. The spectra identified were numbers. The wave numbers were saved and printed (Geethu et al., 2014).

Ethanol Analysis by Gas Chromatography-Mass Spectrometry (GC-MS): The components present in the distilled ethanol were further estimated using GCMS analytical technique. The analysis was performed using GC-MS Shimadzu 8400S system of the National Research Institute for Chemical Technology Laboratory Zaria. One microliter $(1 \mu)$ of the sample was transferred to auto sampler vial and was taken into the analyzer to run the sample. Thereafter a library search was conducted to ascertain the possible functional groups present (Geethu et al., 2014).

Statistical Analysis: Data were analyzed using descriptive statistics, one way Analysis of variance (ANOVA) at $95 \%$ probability level of Significance. Duncan's Multiple Range Test was used to compare the different means (groups).

\section{RESULTS AND DISCUSSION}

Proximate Composition and Total Carbohydrate Content of the Lignocellulosic Biomass: Proximate percentage values of dry matter (DM) in substrates are recorded as 96.60\%, 96.12\%, 95.86\%, 95.09\%, $93.73 \%$, and $92.76 \%$ (Fig. 1). There is no substantial variation of dry matter among the substrates, the highest been 96.60 (rice bran) while the least is 92.76 (corn bran). Also the ash content in the substrates recorded as follows: $17.72 \%, 5.62 \%, 3.53 \%, 1.63 \%$ and $1.07 \%$. Substrates of white saw dust and sorghum bran have the same percentage values of 1.63. The content of ash recorded is $17.72 \%$ for Rice bran and it showed the highest. The crude fibre (CF) content of the substrates show the percentage values of $75.56 \%$, $6839 \%, 63.29 \%, 28.37 \%, 5.17 \%$, and $1.87 \%$. The highest percentage value of $75.56 \%$ was found in white saw dust. Likewise, crude protein (CP) has percentage values ranged from $1.94 \%$ to $12.19 \%$. The highest percentage value of CP is found in corn bran. The results of the lignocelluloses biomass of white saw dust, red saw dust, black saw dust, rice bran, corn bran and sorghum bran revealed cellulose components as $77.78 \%, 75.55 \%, 68.59 \%, 64.83 \%, 54.82 \%$ and $55.14 \%$ respectively; hemicellulose as $6.80 \%, 4.03 \%$, $6.70 \%, 8.62 \%, 9.04 \%$ and $1.34 \%$ respectively; and lignin constituted $1.80 \%, 2.47 \%, 2.39 \%, 1.45 \%$, $2.12 \%$ and $0.85 \%$ respectively (Fig. 2). This study revealed the carbohydrate content of $77.6 \%, 65.4 \%$. $54.0 \%, 51.8 \%, 43.3 \%$ and $35.7 \%$ for red sawdust, black sawdust, corn bran, white sawdust, rice bran and sorghum bran respectively (Fig. 3).

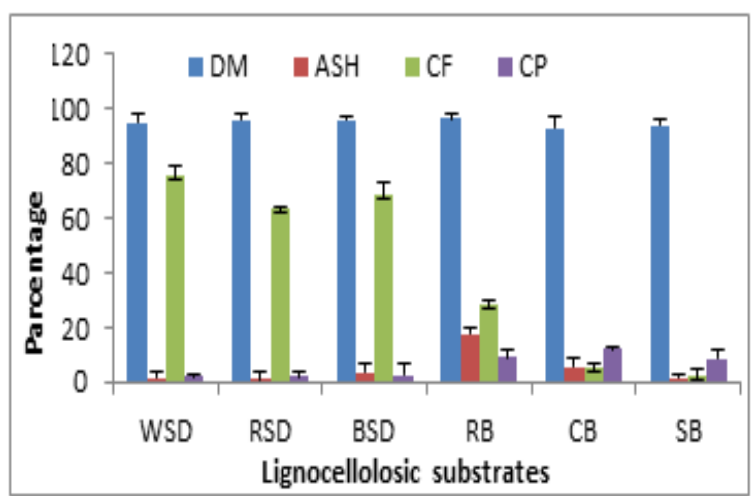

Fig.1. Proximate composition of lignocellulosic substrates. WSD: White saw dust; DM: Dry Matter, RSD: Red saw dust, ASH: Ash content, BSD: Black saw dust, CF: Crude fiber, RB: Rice bran, CP: Crude Protein, CB: Corn bran, SB: Sorghum bran

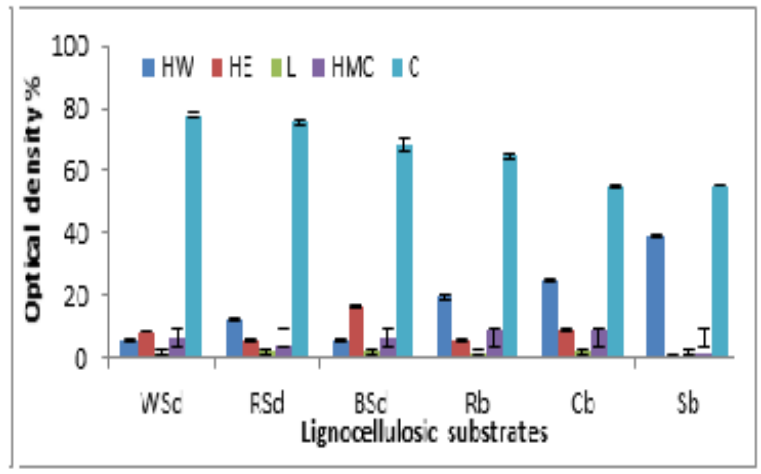

Fig. 2 Chemical Composition of lignocelluloses. WSd: White saw dust, HW: Hot water fractions, RSd: Red saw dust, HE: Hot ethanol fractions, BSd: Black saw dust, L: Lignin fractions, Rb: Rice bran, HMC: Hemicellulose fractions, Cb: Corn bran, C: Cellulose fractions, Sb: Sorghum bran

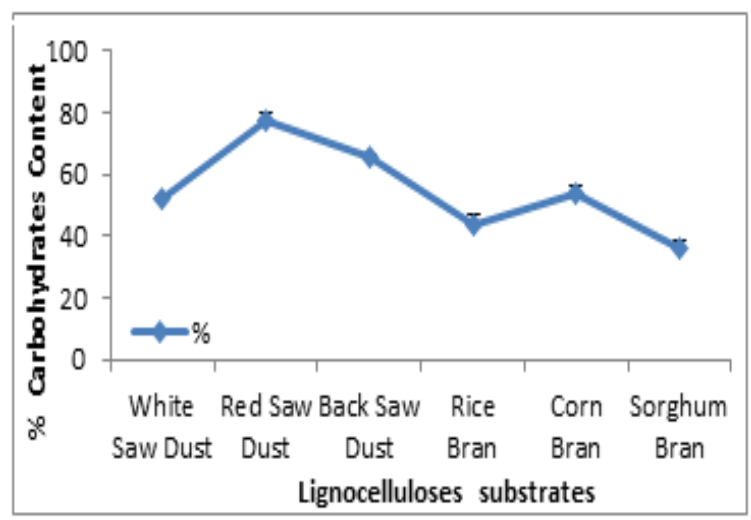

Fig. 3: Percentage total carbohydrate contents of the lignocellulosic biomass

Ash which is a constituent of the lignocellulosic biomasses is an impurity that will not burn. For this reason, biomasses with low ash content are better suited for pyrolysis than biomasses with high ash content. The low values of the ash content generated in this study are in line with the findings of Schild et al. (2010) and Salehi et al. (2013). According to Kim 
et al. (2001), the combustion value and efficacy of biofuel depend on the low ash content. Combustion is another way of converting organic matters with oxygen to produce primarily carbon dioxide and water. The ash content of any biomass has a significant influence on the heat transfer to the surface of the biomass as well as the diffusion of the oxygen to the biomass surface during combustion (Kim et al. 2001; Mitchual et al. 2014). The crude protein and fibre contents in all the residues suggest that, this could be mainly attributed to hydroxyl proline-rich glycoprotein. As reported by Bartolome and Ruperez, (1995) and Smith et al. (1995), the glycoproteins in the shell of fruits are immersed in the primary cell wall forming a network of microfibrils with the cellulose. The results of the substrates component in terms of cellulose, hemicellulose and lignin are similar to the findings of $\mathrm{Hu}$ (2006), Shulga et al. (2007), Song et al. (2012) and Amiri et al. (2014). However variations in the biomass compositions may be attributed to different agronomic and cultural practices adopted for growth of the plants and different method employed for the analysis.

Identification of Yeast Isolates with API 20C AUX Strip: A total of 25 yeast isolates were recovered from the YEPG medium culture of fermented beverages and were identified with high degree of certainty. Using the API 20C AUX system strips (bio Merieux, France) for the identification of yeast isolates, sixteen isolates were identified (Table 1).

Table 1 Biochemical characterization of microbial isolates from Kunu zaki, brukutu and palm wine juice using strip of API 20C AUX

\begin{tabular}{|c|c|c|c|c|c|c|c|c|c|c|c|c|c|c|c|c|c|c|c|c|}
\hline $\begin{array}{l}\mathrm{G} \\
\mathrm{L} \\
\mathrm{U}\end{array}$ & $\begin{array}{l}\mathrm{G} \\
\mathrm{L} \\
\mathrm{Y}\end{array}$ & $\begin{array}{l}2 \\
\mathrm{~K} \\
\mathrm{G}\end{array}$ & $\begin{array}{l}\mathrm{A} \\
\mathrm{R} \\
\mathrm{A}\end{array}$ & $\begin{array}{l}X \\
Y \\
L\end{array}$ & $\begin{array}{l}A \\
D \\
O\end{array}$ & $\begin{array}{l}\text { X } \\
\mathrm{L} \\
\mathrm{T}\end{array}$ & $\begin{array}{l}\mathrm{G} \\
\mathrm{A} \\
\mathrm{L}\end{array}$ & $\begin{array}{l}\mathrm{I} \\
\mathrm{N} \\
\mathrm{O}\end{array}$ & $\begin{array}{l}\mathrm{S} \\
\mathrm{O} \\
\mathrm{R}\end{array}$ & $\begin{array}{l}\mathrm{M} N \\
\mathrm{D} A \\
\mathrm{G}\end{array}$ & $\begin{array}{l}\mathrm{C} \\
\mathrm{B} \\
\mathrm{L}\end{array}$ & $\begin{array}{l}\mathrm{L} \\
\mathrm{A} \\
\mathrm{C}\end{array}$ & $\begin{array}{l}\text { M } \\
\text { A } \\
\text { L }\end{array}$ & $\begin{array}{l}\mathrm{S} \\
\mathrm{A} \\
\mathrm{C}\end{array}$ & $\begin{array}{l}\mathrm{T} \\
\mathrm{R} \\
\mathrm{E}\end{array}$ & $\begin{array}{l}\text { M } \\
\mathrm{L} \\
\mathrm{Z}\end{array}$ & $\begin{array}{l}\mathrm{R} \\
\mathrm{A} \\
\mathrm{F}\end{array}$ & $\begin{array}{l}\text { Hyphae' } \\
\text { Pseudo- } \\
\text { Hyphae }\end{array}$ & $\begin{array}{l}\text { API } \\
\text { Profile } \\
\text { Coding }\end{array}$ & IDENTITY \\
\hline+ & + & - & - & - & - & - & + & - & - & $-\quad-$ & - & - & + & - & $\mathrm{V}$ & $\mathrm{V}$ & + & + & 60400 & Sacc haromalc es cerevisiae 1 \\
\hline+ & - & - & - & - & - & - & + & $\mathrm{V}$ & + & - & - & - & + & + & - & - & - & + & 2042034 & Sacc haromac es cerevisiae 2 \\
\hline+ & + & $\mathrm{V}$ & $\mathrm{V}$ & $\mathrm{V}$ & $\mathrm{V}$ & - & - & $\mathrm{V}$ & - & $-V$ & - & - & - & + & + & - & - & + & 6000064 & Sporobolomyces strain \\
\hline+ & + & - & - & + & - & - & V & - & + & $-V$ & - & V & - & - & - & - & - & + & 6442004 & Geotrichwn klebahnitidum \\
\hline+ & + & + & V & + & - & V & + & - & + & ++ & + & + & + & + & + & + & $\mathrm{V}$ & + & 6556775 & Candida fencuta \\
\hline+ & + & + & $\mathrm{V}$ & + & - & - & - & - & - & -+ & - & - & - & + & + & - & - & + & 6500164 & Rhodotorila misuta \\
\hline+ & + & V & $\mathrm{V}$ & $\mathrm{V}$ & - & $\mathrm{V}$ & + & $\mathrm{V}$ & $\mathrm{V}$ & ++ & $\mathrm{V}$ & $\mathrm{V}$ & + & + & + & + & + & + & 6044177 & Sacc harowac es cerevisiae 3 \\
\hline+ & + & + & V & + & $\mathrm{V}$ & $\mathrm{V}$ & + & $\mathrm{V}$ & - & ++ & + & + & + & + & + & + & + & + & 6544777 & Trichosporon mucoides \\
\hline+ & + & + & $\mathrm{V}$ & + & + & $\mathrm{V}$ & + & $\mathrm{V}$ & + & ++ & $\mathrm{V}$ & $\mathrm{V}$ & + & + & + & + & $\mathrm{V}$ & + & 6556175 & Candida parapsilosis \\
\hline+ & $\mathrm{V}$ & + & + & + & $\mathrm{V}$ & + & + & $\mathrm{V}$ & + & ++ & + & + & + & + & + & + & + & + & 2766777 & Cryptococcus lawrentü \\
\hline+ & + & - & - & - & - & - & V & - & + & $+V$ & $\mathrm{~V}$ & $\mathrm{~V}$ & + & - & + & + & $\mathrm{V}$ & + & 6006055 & Candida pellic ulosa \\
\hline+ & + & + & V & + & + & $\mathrm{V}$ & + & + & V & ++ & + & $\mathrm{V}$ & + & + & + & + & $\mathrm{V}$ & + & 6556375 & Candida Lusitaniae 1 \\
\hline+ & $\mathrm{V}$ & + & V & $\mathrm{V}$ & $\mathrm{V}$ & $\mathrm{V}$ & + & V & $\mathrm{V}$ & V V & $\mathrm{V}$ & $\mathrm{V}$ & $\mathrm{V}$ & + & + & $\mathrm{V}$ & + & + & 2140066 & Candida collic ubsa \\
\hline+ & + & $\mathrm{V}$ & V & + & - & - & + & V & + & V V & - & - & - & - & - & $\mathrm{V}$ & V & + & 6442004 & Geotrichwn candidun \\
\hline+ & + & + & V & + & + & $\mathrm{V}$ & V & $\mathrm{V}$ & $\mathrm{V}$ & $\mathrm{V}+$ & & - & + & + & + & + & V & + & 6510175 & Candida Lusitaniae 2 \\
\hline+ & + & + & $\mathrm{V}$ & + & + & - & $\mathrm{V}$ & $\mathrm{V}$ & V & $V+$ & & - & + & + & + & + & $\mathrm{V}$ & + & 6510175 & Candida Lusitrniae 3 \\
\hline
\end{tabular}

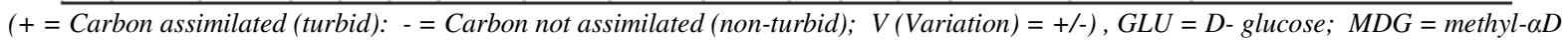
- glucopyranosides; $G L Y=$ Glycerol; $N A G=N$-acetyl-glucosamine; $2 K G=2-$ keto-gluconate $; C E L=D$ - cellobiose $;$ ARA = Larabinose; $M A L=D$-Maltose $; X Y L=D$-xylose $; S A C=D$-Saccharose (sucrose); $A D O=$ Adonitol $;$ TRE $=D$-Trehalose $; X L T=X y l i t o l$; $M L Z=D$-Melezitose $; G A L=D-$ Galactose $; R A F=D-$ Raffinose $; I N O=$ Inositol $;$ LAC $=D$-Lactose $;$ SOR $=D-S o r b i t o l$.

Ethanol Tolerance of the Yeast Isolates: The ethanol tolerance of the yeast isolates showed ranges from $6 \%$ to $14 \%$ (Table 2). The yeast Isolates $\mathrm{K} 2, \mathrm{~B} 5, \mathrm{~B} 7$ and P1 had the highest tolerance percentage value of $14 \%$ while the least tolerance percentage value of $0.6 \%$ were recorded for $\mathrm{B} 8, \mathrm{P} 3$, and $\mathrm{P} 4$ respectively. As concentration of ethanol increases in media, a reduction in growth is generally observed. Ethanol tolerance of isolates is taken at the very concentration of ethanol after which there was a sharp decrease in growth. Ethanol tolerance of yeast is important in fermentation because high production of ethanol requires yeast that can withstand high concentrations of ethanol. During production, this ethanol is known as an inhibitor of microbial growth. It damages mitochondrial DNA in yeast cells and causes inactivation of some enzymes, such as hexokinase and dehydrogenase (Ibeas and Jimenez, 1997). This is because plasma membranes of the unicellular organisms are in direct contact with the surrounding culture medium. It is likely that its characteristics will influence tolerance of cells to all kinds of changes occurring during fermentation (Herrera, 2001). Ethanol tolerance of seven yeast strains isolated from fruits by Tikka et al. (2013) reported maximum tolerance of $12 \%$ by one of the yeasts YDE. Also, this result is in agreement with the findings of Ergun and Ferda (2000), who reported to have obtained two yeast strains that tolerated $14 \%$ ethanol. The baker yeast was able to tolerate maximum of $12 \%$ ethanol, and beyond this concentration growth was decreased exponentially as shown by drops in optical density values. $\mathrm{K} 1, \mathrm{~K} 3$, $\mathrm{K} 5, \mathrm{~K} 6, \mathrm{~K} 9, \mathrm{~B} 3$ and P6 isolates tolerated ethanol concentration up to $10 \%$. K4, K7, B4, P2, P5 and P7 isolates tolerated ethanol concentrations up to $8 \%$. 
Ethanol-Producing Ability of the Yeast Isolates: The results showed that the ethanol-producing ability of the yeast isolates ranged from $4.1 \%$ to $10.3 \%$ (Table 2 ). The highest percentage was observed in P1 and the least ethanol-producing percentage value of $4.1 \%$ was observed in K3. Ethanol production and recovery does not only depend on the substrates used but also depends on the efficiency of yeast strains to convert the reducing sugars to ethanol. According to Kurtzman (1998), all ethanol contained in alcoholic beverages is produced by means of fermentation induced by yeast. The diversity of yeast in indigenous fermented beverages utilized for the research showed that most traditional fermentation employ the whole range of natural microflora that could function under the varied environmental and non-sterile conditions presented by the different processes.

Table 2: Ethanol tolerance and Ethanol Production of Yeast levels of the identified yeast isolates

\begin{tabular}{|c|c|c|}
\hline $\begin{array}{l}\text { Yeast } \\
\text { Isolates }\end{array}$ & $\begin{array}{c}\text { Ethanol Tolerance } \\
(\%) \text { and } \pm \text { S.D }\end{array}$ & $\begin{array}{l}\text { Ethanol Production } \\
(\%) \text { and } \pm \text { S.D }\end{array}$ \\
\hline K1 & $10^{c} \pm 0.1000$ & $5.7^{\mathrm{i}} \pm 0.1789$ \\
\hline K2 & $14^{\mathrm{a}} \pm 0.1340$ & $6.0^{\mathrm{h}} \pm 0.2908$ \\
\hline K3 & $10^{\mathrm{c}} \pm 0.1000$ & $4.1 \pm 0.3650$ \\
\hline K4 & $08^{\mathrm{d}} \pm 0.2165$ & $4.2 \pm 0.2000$ \\
\hline K5 & $10^{c} \pm 0.1000$ & $5.1 \pm 0.1750$ \\
\hline K6 & $10^{c} \pm 0.1670$ & $5.4^{\mathrm{j}} \pm 0.2800$ \\
\hline K7 & $08^{\mathrm{d}} \pm 0.2500$ & $7.4^{\mathrm{e}} \pm 0.2500$ \\
\hline K8 & $12^{\mathrm{b}} \pm 0.3000$ & $6.9^{\mathrm{g}} \pm 0.1000$ \\
\hline K9 & $10^{c} \pm 0.1000$ & $6.2^{\mathrm{g}} \pm 0.3590$ \\
\hline B1 & $12^{\mathrm{b}} \pm 0.3000$ & $7.7^{\mathrm{d}} \pm 0.2001$ \\
\hline B2 & $12^{\mathrm{b}} \pm 0.2570$ & $6.2^{\mathrm{g}} \pm 0.1399$ \\
\hline B3 & $10^{\mathrm{c}} \pm 0.1092$ & $4.2 \pm 0.2006$ \\
\hline B4 & $08^{\mathrm{d}} \pm 0.3578$ & $5.2 \pm 0.3555$ \\
\hline B5 & $14^{\mathrm{a}} \pm 0.1330$ & $5.0 \pm 0.2567$ \\
\hline B6 & $12^{\mathrm{b}} \pm 0.1333$ & $5.2 \pm 0.3333$ \\
\hline B7 & $14^{\mathrm{a}} \pm 0.2560$ & $5.5^{\mathrm{j}} \pm 0.1000$ \\
\hline B8 & $06 \pm 0.1080$ & $5.0 \pm 0.3560$ \\
\hline P1 & $14^{\mathrm{a}} \pm 0.3600$ & $10.3^{a} \pm 0.2890$ \\
\hline $\mathrm{P} 2$ & $08^{\mathrm{d}} \pm 0.2350$ & $8.5^{\mathrm{b}} \pm 0.3678$ \\
\hline P3 & $06 \pm 0.1950$ & $8.2^{c} \pm 0.2680$ \\
\hline P4 & $06 \pm 0.1007$ & $7.5^{\mathrm{e}} \pm 0.9280$ \\
\hline P5 & $08^{d} \pm 0.2560$ & $7.1^{\mathrm{f}} \pm 0.3560$ \\
\hline P6 & $10^{c} \pm 0.1006$ & $4.2 \pm 0.7779$ \\
\hline P7 & $08^{\mathrm{d}} \pm 0.2580$ & $4.4 \pm 0.8260$ \\
\hline P8 & $12^{\mathrm{b}} \pm 0.1592$ & $6.0^{\mathrm{h}} \pm 0.7520$ \\
\hline Baker & $12^{\mathrm{b}} \pm 0.2560$ & $6.2^{\mathrm{g}} \pm 0.5560$ \\
\hline \multicolumn{3}{|l|}{ Yeast } \\
\hline $\mathrm{SE} \pm$ & 0.297 & 6.258 \\
\hline
\end{tabular}

The result of ethanol production is similar to the findings of Gupta et al. (2009) who reported less than $12.5 \%$ ethanol produced by Saccharomyces cerevisiae. Similarly, this agrees with the findings of Patil and Patil (2006) who reported $8.33 \%$ by $S$. ellipsoideus 101. The yeast isolates are found to have utilized some amounts of sugar during the batch fermentation period (72 hours) but not all isolates are efficient in ethanol production. Three yeast isolates are efficient ethanol producers: P1, P2 and P3. This finding proved that Saccharomyces cerevisiae is more efficient for ethanol production compared to other species (Ergun and Ferda, 2000). This is due to the fact that some species adopt different metabolic pathways by having special genes or enzymes such as invertase genes and invertase enzymes respectively for the conversion of sugars to ethanol or other metabolites (Fregonesi et al., 2007). The average ethanol yield during substrate fermentation is very similar to that of Ezeogu and Emeruwa (1993) who reported 12.2\% yield of ethanol for Sake-type fermentation using Nigerian palm wine Saccharomyces cerevisiae. However, the ethanol contents produced were also similar as compared to those produced by industrial yeast strains in Japan, in which the ethanol content was reported to be $17.0 \%$ to $19.0 \%$ as reported by Yoshizawa and Kishi (1994). Differences in the ethanol levels may be due to the variability in fermentative capacities of yeast strains.

Fourier Transform Infrared Spectrophotometer (FTIR) and Gas Chromatography and Mass Spectrometry (GC-MS) Analyses: The FTIR showed the presence of peaks range between $1697 \mathrm{~cm}^{-1}$ and $1512 \mathrm{~cm}^{-1}, 1813 \mathrm{~cm}^{-1}$ and $1797 \mathrm{~cm}^{-1}, 3286 \mathrm{~cm}^{-1}$ and $2985 \mathrm{~cm}^{-1}, 3456 \mathrm{~cm}^{-1}$ and $3371 \mathrm{~cm}^{-1}$ which suggests the presence of $\mathrm{C}=\mathrm{N}, \mathrm{N}-\mathrm{H}$ bend, $\mathrm{C}=\mathrm{O}$ stretch, $\mathrm{R}-\mathrm{CO}-\mathrm{NH}_{2}$, $\mathrm{O}-\mathrm{H}$ stretch, $\mathrm{C}-\mathrm{H}$ stretch, $\mathrm{H}-\mathrm{C}=\mathrm{O}$ stretch, and $\mathrm{R}-\mathrm{C}=\mathrm{C}-$ $\mathrm{H}$. The results suggest that all the functional groups present are majorly alcohol $(\mathrm{O}-\mathrm{H})$ at the absorption range. GC-MS revealed that the most common compounds detected after the fermentation by yeasts are as follows: 3-floro-B, 5-dihydroxy-N-methylbenzeneethanamine, (R)-(-)-2-Amino-1-propanol. Other compounds detected are Methylhydrazine, 2Aziridinylethylamine, Topotecan, 4-[2(Methylaminol) ethyl-1,2-benzendiol and 2Fonnylhistamine. Hydroxyl-urea was only detected in sorghum bran. Ethanol was majorly detected in all the tested lignocellulosic substrates. Ethanol is one of many kinds of alcohol. It is also known as ethyl alcohol and can be distinguished based on their molecular structure. The result of FTIR spectroscopic and GC-MS analyses are similar to the findings of Pankajkumar et al. (2014) who investigated structural changes in waste lignocellulosic material. According to Geethu et al. (2004), FTIR spectrum is able to predict the phytoconstituents in Calotropis gigantea produced after dye bioremediation under solid state fermentation.

Conclusion: The study revealed that the lignocellulosic composition differed from one substrate to another. It is observed from this study that yeasts from fermented beverages that can be utilized 
for bioethanol production, and that Saccharomyces cerevisiae isolated from palm wine is best in ethanol tolerance and ethanol production. Lignocellulosic biomasses are recommended as raw materials for producing ethanol, a promising alternative energy source as against the depleting crude oil. This study also recommends the application of biological engineering for increased ethanol production.

\section{REFERENCES}

Amiri, H., Karim, K. and Zilouei, H. (2014). Organosolv pretreatment of rice straw for efficient acetone, butanol, and ethanol production. Bioresource Technology. 152: 450 - 456.

Association of Official Analytical Chemists, AOAC. (1990). Official methods of analysis international, MD, USA.

Bartolome, A.P., Ruperez, P. and Prieto, A. (1995). Polysaccharide from Cell Walls of Pineaple Fruit. Journal of Agricultural and Food Chemistry. 43:608-612.

Balat M., Balat, H. and Oz, C. (2008). Progress in bioethanol processing, Progress in Energy and Combustion Science. Applied Energy, 34:551 573.

Cardona, C.A. and Sanchez, O.J. (2007). Fuel ethanol production: Process design trends and intergration opportunities. Bioresource Technology. 98:2415 $-2457$.

Dawson, L. and Boopathy, R. (2007). Use of postharvest sugarcane residue for ethanol production. Bioresource Technology. 98: 1695 - 1699.

Ergun, M. and Ferda, M.S. (2000). Application of a statistical technique to the production of ethanol from sugar beet molasses by Saccharomyces cerevisiae. Bioresource. Technology. 73:251-255.

Ezeogu, L.I. and Emeruwa, A.C. (1993). High level ethanol-tolerant Saccharomyces from Nigerian Palm wine. Biotechnology Letter. 15: 83 - 86.

Fregonesi, A., Moran-Paulo, J. and Jookes, I. (2007). Continuous fermentation of sugar cane syrup, using immobilized yeast cells. Bioresource Bioengineering. 97:48-52.

Geethu, M.G., Sucthra, P.S., Kavitha, C.H., Aswathy, J.M., Dinesh Babu and Murugan, K., (2004). Fourier transform infrared spectroscope analysis of different solvent extracts of water hygcinth (Leichormia Crapsipes most solutions) on allopathic approach. World journal of Pharmacy and Pharmaceutical Sciences. 3(6): 1256 - 1266.

Gupta, N., Dubey, A. and Tewari, L. (2009). High efficiency alcohol tolerant Saccharomyces isolates of Phoenix dactylifera for bioconversion of sugarcane juice into bioethanol. Journal of Scientific and Industrial Research. 68:401-405

Harper, S.H.T. and Lynch, S.M. (1981). The chemical components and decomposition of wheat straws, leaves, internodes and nodes. Journal of Science Food Agriculture. 323:1057-1062.

Herrera, G. (2001). Yeasts and molds - Methods in biotechnology: Food Microbiology protocols by Spencer T. and Ragout S. Humana Press Totowa. New Jersey; 14: 27 - 28.

Hu, Z., Yeh, T.F., Chang, H., Matsumoto,Y. and Kadla, J.F. (2006). Elucidation of the structure of cellulolytic enzyme lignin. Holzkorschung 60(4): $389-397$.

Ibeas, J.I. and Jimenez, J. (1997). Mitochondrial DNA loss caused by ethanol in Saccharomyces cerevisiae flour yeasts. Applied Environmental Microbiology. 63: 7 - 12 .

Kang, Q., Appels, L., Deasil, R. and Tan, T. (2014). Energy-efficient production of cassava-based bioethanol, Advances in Bioscience and Biotechnology. 5:925-939.

Kim, H.J. Lu, G.Q., Naruse, I., Yuan, J. and Ohtake, K. (2001). "Modelling combustion characteristics of bio-coal briquettes", Journal of Energy Resources Technology. 123, 27 - 31.

Kurtzman, C.P. and C.J. Robnett. (1998). Identification and phylogency of ascomycetous yeasts from analysis of nuclear subnunit (265) ribosomal DNA partial sequences. Antonie/Leeuwenhoek 73:331 - 371.

Martini, A., Ciani, M. and Scorzetti, G. (1996). Direct enumeration and isolation of wine yeasts from grape surfaces. American Journal of Enology and viticulture 47: 435-440

Mitchual, J.S., Frimpong-Mensah, K. and Darkwa, A.N. (2014). "Evaluation of fuel properties of six tropical hardwood timber of species for briquettes, Journal of sustainable Bioenergy Systems 4: 1-9. 
Nzelibe, H.C. and Okafoagu, C.U. (2007). Optimization of ethanol production from Garcinia kola (bitter cola) pulp agro waste. African Journal Biotechnology 6 (17): 2033 - 2037.

Okuda, N., Ninomiya, k., Takao, M., Katokura, Y. and Shioya, S. (2007). Microaeration enhances productivity of bioethanol from hydrolysate of waste house wood using ethanologenic Escherichia coli K011. Journal of Bioresource Bioengineering. 62: 447 - 454.

Osho, A. (2010). Traditional Complement Alern Medicine. African Journal 7: 303-308.

Pankajkumar, R.W., Avinash, A.K., Ganesh, D.S. and Sanjay, P.G. (2014). Enzymatic hydrolysis and Characterization of waste lignocellulosic biomass produced after dye bioremediation order solid state fermentation. Journal Bioresource Technology. 13: 1-6.

Patil, S.K., and Patil, A.B. (2006). Isolation and characterization of wine yeast from pineapple fruits. Karnataka, Journal of Agricultural Sciences. 19(3): $558-561$.

Prasad, S, Singh A, Joshi. HC. (2007). Ethanol as an Alternative Fuel from Agricultural, Industrial and Urban residues. Resource Conserved Recycle, 50, 1-39.

Saha, B.C. (2003). Hemicelluloses bioconversion. Journal of Industrial Microbiology and Biotechnology; 30: 279 - 291.

Salehi, E., Abedi, J., Harding, G.T. and SeyedeynAzad, F. (2013). "Bio-oil from sawdust: Design, operation, and performance of a bench-scale fluidized bed pyrolysis plant," Energy and fuels. 27: $3332-3340$.

Sa-Pereira, P. H., Paveia, M., Costa-Ferreira and Aires-Barros, M.R. (2003). A new look at xylanases: An overview of purification strategies. Molecular Biotechnology., 24: 257 - 281.
Schild, G., Sixta, H. and Testova, L. (2010). "Multifunctional alkaline pulping, delignification and hemicelluloses extraction," Cellulose Chemistry and Technology, 44 (1): 35 - 45.

Shulga, G., Betkers, T., Shakels, V., Neiberte, B., Verovkins, A., Brovkina, J., Belous, O., Ambrazaitene, D. and Zukauskaite, A. (2007). Effect of the modification of lignocellulosic materials with a lignin-polymer complex on their Mulching properties, Bioresource. 2(4): 572 582.

Smith, B. and Harris, P. (1995). Polysaccharide Composition of Unlignified Cell Walls of Pineapple (Ananas Comosus L. Mess.) Fruit. Plant Physiology. 107: 1399-1409

Song, Z., Yang, G., Guo, Y. and Zhang, T. (2012). Comparison of two chemical pretreatments of rice straw for biogas production by anaerobic digestion. Bioresources 7(3): 4333 - 3236.

Tikka, C., Osuru, H.P. and Alluri, N. (2013). Isolation and characterization of ethanol tolerant yeast strains. Bio-information 9(8): 421 - 425.

Wyman, C.E. and Himman, N.D. (1990). Ethanol fundamentals of production from renewable feed stock and use as a transportation fuel. Applied Biochemistry and Biotechnology. 24 - 25: 735 753.

Yoshizawa, K. and Kishi, S. (1994). Rice in Brewing. 619-645. In: Juliano, Bro. (Ed.) Rice chemistry and Technology. The American Association of Cereal Chemists, Inc. USA.

Zhang, M., Shukla, P., Ayyachamy, M., Permaul, K. and Singh, S. (2010). Improved bioethanol production through simultaneous saccharification and fermentation of lignocellulosic agricultural wastes by Kluyveromyces marxianus 6556. World Journal of Microbiology Biotechnology. 26: 1041 - 1046. 